\title{
Study of the Optimal Physical Parameters and Action of the Proteolytic Enzyme on the Antimicrobial and Antioxidant Potential of the Protein Isolated from Different Pulses
}

\author{
Shahana Jabi ${ }^{1 *}$ and Abhishek Mathur ${ }^{2}$ \\ ${ }^{1}$ Department of Biotechnology, Himalayan University, Arunachal Pradesh, India \\ ${ }^{2}$ R\&D cum New product Development, EBEC-NCFT, New Delhi, India \\ *Corresponding author
}

\section{A B S T R A C T}

\begin{tabular}{l} 
Ke y w or d s \\
Antimicrobial \\
potential, \\
Antioxidant \\
potential, \\
Cicer arietinum, \\
protein, \\
Vigna radiata. \\
\hline Article Info \\
\hline $\begin{array}{l}\text { Accepted: } \\
\text { 17 June 2017 } \\
\text { Available Online: } \\
\text { 10 August } 2017\end{array}$ \\
\hline
\end{tabular}

In the present study, proteins were extracted and purified from germinated seeds viz. Vigna radiata (mung bean), Cicer arietinum (gram white and gram black). The protein extracted was evaluated for any antimicrobial effects against the different pathogens and to determine antioxidant potential. The studies were performed to assess the effect of $\mathrm{pH}$, temperature and proteolytic enzymes on the antimicrobial nature of the protein extracted. It was found that the extracted antimicrobial protein had prominent antimicrobial effect on the different microbial pathogens at the range of $\mathrm{pH} 4-7$. The studies also showed the strong antioxidant potential of the different seeds protein isolated and purified. It was also observed that the temperature from $25^{\circ} \mathrm{C}-30^{\circ} \mathrm{C}$ has no adverse effect on the antimicrobial action of the proteins extracted. The results of the present study thus help to explore and formulate the potent antimicrobial agent against different variety of pathogens and to formulate strong antioxidant agent.

\section{Introduction}

Plants have been a precious source of natural products for sustaining human health. According to World Health Organization (Anonymous, 2008) more than $80 \%$ of the world's population relies on traditional medicine for their primary healthcare needs.

Therefore medicinal plants need to be investigated for better understanding in respect to their properties, safety and efficiency. One of such properties like antimicrobial activity can be of great significance in therapeutic treatments. Especially with the emergence of antibiotic resistant microbes which have become a major health threat over the past decades (Wright, 2000). According to Marx (2005), the continuous use of analogous antibiotics has resulted in multi-resistant bacterial strains all over the world. Presently it is being broadly predictable that in the very near future antibiotic resistance will make healthcare professionals helpless toward effective therapies for bacterial infections. 
Consequently there is an urgent need to search for unconventional antibiotics. Therefore as an upshot, interest in peptide antibiotics has increased greatly during the past decade, as these are believed to be very potent, showing higher activity, higher specificity, having few toxicology problems, do not accumulate in organs, few drug-drug interaction challenges and are biological and chemical diverse.

It has been shown in certain studies that plants protect themselves against microbial pathogens by various defense responses including production of antimicrobial peptides (AMPs), secondary metabolites, lytic enzymes and membrane-interacting proteins (Feng et al., 2003).

\section{Materials and Methods}

\section{Protein extraction}

The leguminous seeds were collected from the local markets of Uttarakhand (Images 1 and 2).

The modified strategy used for protein extraction (Gao et al., 2000; Pasha et al., 2016) is described in the following steps-

Seeds were washed with $\mathrm{HgCl}_{2}$ and further taken for the study $(10 \mathrm{~g}-100 \mathrm{~g})$

Crushed and blended with $150 \mathrm{ml}$ of PBS at $4^{\circ} \mathrm{C}$.

Frozen and thawn 3-4 times.

Centrifuged at 10, $000 \mathrm{rpm}$ for 10 minutes at $4^{\circ} \mathrm{C}$.

After centrifugation, pellet and supernatant fractions were obtained. Supernatant fractions were subjected to $75 \%$ ammonium sulphate precipitation while pellet fractions were discarded. Further centrifugation (10, 000 rpm for 1 hour at $25^{\circ} \mathrm{C}$ ) of the ammonium sulphate precipitated fractions was done to obtain the pellet.

The pellet fractions were solubilized in deionized water and were followed for dialysis and SDS PAGE.

Further Gel-column chromatography of the pellet fractions was performed in order to obtain the pure crude fractions.

Furthermore SDS-PAGE analysis of the pure fractions eluted was performed.

\section{Column gel chromatography of eluted protein fractions}

About $2 \mathrm{ml}$ having $\sim 500 \mu \mathrm{g} / \mathrm{ml}$ protein concentration of this sample was applied onto the $1.5 \times 70 \mathrm{~cm}$ column of Sephadex G-100 pre-equilibrated with $0.02 \mathrm{M}$ Sodium acetate buffer ( $\mathrm{pH} 4.5)$. The column was eluted with the same buffer at the rate of $1 \mathrm{ml} / 1 \mathrm{~min}$. The elution pattern was monitored by taking absorbance of collected fractions at $280 \mathrm{~nm}$ (Jaladi et al., 2015).

\section{SDS-PAGE analysis of eluted protein fractions and Quantitative estimation by Folin- Ciocalteau's reagent}

The fractions along with crude extract and solublized ammonium sulphate precipitated protein were run on sodium dodecyl sulphate polyacrylamide gel electrophoresis (SDSPAGE) using $12 \%$ - 14\% gel by method described (Laemmli, 1970). The gels were stained with Coomassie brilliant blue R-250 and distained with methanol: acetic acid: water $(30: 60: 10 \mathrm{v} / \mathrm{v})$. The approximate molecular weight of fractions activity was determined by plotting Rf versus molecular weight of known standard proteins. Protein fractions isolated and purified from seeds was 
determined (Lowry et al., 1951). Absorbance was measured at $750 \mathrm{~nm}$ in UV-VIS spectrophotometer.

\section{Determination of antibacterial activity}

\section{Culture Media}

For antibacterial test, Soyabean Casein Digest agar/broth of Hi Media Pvt. Bombay, India was used.

\section{Inoculum}

The bacteria viz. Bacillus subtilis, Bacillus (spreader) and Micrococcus luteus were inoculated separately into Soyabean casein digest broth and incubated at $37^{\circ} \mathrm{C}$ for $18 \mathrm{~h}$ and suspension was checked to provide approximately, $10^{5} \mathrm{CFU} / \mathrm{ml}$.

\section{Determination of diameter of zone of inhibition by well diffusion method}

The agar well diffusion method (Perez et al., 1993) was modified. Soyabean casein digest agar medium (SCDM) was used for bacterial cultures. The culture medium was inoculated with the bacteria separately suspended in nutrient broth.

A total of $8 \mathrm{~mm}$ diameter wells were punched into the agar and filled with protein extracts prepared in N-saline at $1.0 \mathrm{mg} / \mathrm{ml}$ concentration. Standard antibiotic (Erythromycin, $1 \mathrm{mg} / \mathrm{ml}$ ) was simultaneously used as the positive control. The plates were incubated at $37^{\circ} \mathrm{C}$ for $18 \mathrm{~h}$.

The antibacterial activity was evaluated by measuring the diameter of zone of inhibition observed. The procedure for assaying antibacterial was performed in triplicates to confirm the readings of diameter of zone of inhibition observed for each of the test organism.

\section{Determination of antioxidant activity}

\section{Estimation of Total Phenolic Content (TPC) of protein (s) isolated}

The total phenolic content of the protein fractions were determined by the method of Singleton and Rossi (1965). The phenolic content was expressed as $\mathrm{mg} / \mathrm{g}$ gallic acid equivalents. In brief $100 \mu \mathrm{l}$ aliquots of the sample were added to $2 \mathrm{ml}$ of $0.2 \%(\mathrm{w} / \mathrm{v})$ $\mathrm{Na}_{2} \mathrm{CO}_{3}$ solution.

After 2 minutes of incubation, $100 \mu \mathrm{l}$ of 500 $\mathrm{ml} / 1$ Follin-Ciocalteu reagent were added and the mixture was allowed to stand for 30 minutes at $25{ }^{\circ} \mathrm{C}$. The absorbance was measured at $750 \mathrm{~nm}$ using a UV-VIS Systronics spectrophotometer. The blank consist of all reagents and solvents but no sample. The total phenolic content (TPC) was determined using the standard gallic acid calibration curve.

\section{Determination of superoxide anion radical scavenging activity}

Superoxide anion radical scavenging activity was measured with some modifications (Duan et al., 2007). The various fractions of proteins were mixed with $3 \mathrm{ml}$ of reaction buffer solution $(\mathrm{pH}, \quad 7.4)$ containing $1.3 \mu \mathrm{M}$ riboflavin, $0.02 \mathrm{M}$ methionine and $5.1 \mathrm{uM}$ NBT separately.

The reaction solution was illuminated by exposure to $30 \mathrm{~W}$ fluorescent lamps for 20 minutes and the absorbance were measured at $360 \mathrm{~nm}$ using a spectrophotometer. Ascorbic acid was used as positive control and the reaction mixture without any sample were used as negative control. The percent inhibition of superoxide anion radical scavenging activity (\%) was calculated as:

$\left[\left(\mathrm{A}_{\mathrm{o}}-\mathrm{AS}\right) / \mathrm{A}_{0}\right] \mathrm{x} 100$ 
Where, $\mathrm{A}_{0}=$ absorbance of positive control; $\mathrm{A}_{\mathrm{S}}=$ absorbance of sample

\section{Determination of total antioxidant activity}

Total antioxidant activities of protein fractions isolated and standard ascorbic acid were determined. An aliquot $(0.1 \mathrm{M})$ of these fractions were combined with $1 \mathrm{ml}$ of reagent solution (0.6 M sulphuric acid, $28 \mathrm{mM}$ sodium phosphate and $4 \mathrm{mM}$ ammonium molybdate).

The tubes were then after capped and incubated at $95^{\circ} \mathrm{C}$ for 90 minutes. After that the sample were cooled at $25^{\circ} \mathrm{C}$, the absorbance were measured at $695 \mathrm{~nm}$ against blank. The blank contained $1 \mathrm{ml}$ of reagent solution without sample. The total antioxidant activity was expressed as an absorbance value at $695 \mathrm{~nm}$. Higher absorbance value indicates the maximum antioxidant activity.

Effect of enzyme, temperature and pH on the antimicrobial and antioxidant activities of eluted protein fractions

Protein enzymes (Corolase/Neutral protease and papain) were used for treating the protein fractions eluted in order to check their effect on antimicrobial and antioxidant activities (Carol et al., 2005). Purified peptide samples of $3-20 \mu \mathrm{g} / 10 \mu \mathrm{l}$ were mixed in $0.02 \mathrm{M}$ Tris$\mathrm{HCl}, \mathrm{pH} 6.8$ and then $1-2 \mathrm{U} / 2 \mu \mathrm{l}$ of enzyme was added into the mixture having final reaction volume $100 \mu \mathrm{l}$ and kept for 5 minutes.

The activity of enzyme was stopped by heating the solution in thermo mixer for 5 minutes. The effect of various temperature and $\mathrm{pH}$ was also checked on antimicrobial and antioxidant activities of purified peptide(s). The purified peptides were mixed in $0.02 \mathrm{M}$ Tris- $\mathrm{HCl}, \mathrm{pH} 6.8$ and were heated to different temperatures viz. $0,4,25,50^{\circ} \mathrm{C}$ for 10 minutes and then bioassayed for both the activities. Similarly, the $\mathrm{pH}$ stability of purified peptides was determined between the different ranges of $\mathrm{pH}$ viz. $4,5,6,7$ and 8 using $0.02 \mathrm{M}$ sodium acetate and Tris- $\mathrm{HCl}$ as buffer solution.

\section{Results and Discussion}

In the present study, the protein extracted from the seeds of leguminous plants viz. Mung bean, White and brown gram were screened for antimicrobial activity against the selected contaminants found in molasses and food material. The protein extracted was also check for stability profile by treatment at variable temperature, $\mathrm{pH}$ and proteolytic enzymes.

It was found that the proteins extracted from seeds showed prominent antimicrobial and antioxidant potential against the pathogens studied. It was also observed that the antimicrobial and antioxidant potential of these isolated protein samples changes as per the variation in $\mathrm{pH}$, temperature and action of proteolytic enzymes.

The results are shown in tables 1-8 and figures 1-7. Previous studies have reported many antimicrobial peptides isolation from common vegetables and spices (Ngai and $\mathrm{Ng}$, 2004; Hu et al., 2004; Oard et al., 2004; Xia and Ng, 2005; Ngai et al., 2005; Mariângela et al., 2006).

Previous studies by our group have already described the isolation, characterization and antimicrobial nature of the protein isolated from Vigna radiata (Jabi and Mathur, 2017). Plants are constantly challenged by pathogens, but the onset of plant disease is the exception rather than the rule. The reason for this being that the constant arms race between pest and plant host has led to the development of an efficient plant defense system. 
Table.1 Standard biochemical features of the protein isolated from pulses seeds

\begin{tabular}{|c|c|c|c|}
\hline \multirow{2}{*}{$\begin{array}{c}\text { Types of seeds } \\
\text { protein }\end{array}$} & Strains & \multicolumn{2}{|c|}{$\begin{array}{c}\text { Diameter of zone of inhibition (mm) } \\
\text { Enzymes }\end{array}$} \\
\cline { 3 - 4 } & & $\begin{array}{c}\text { After treatment with } \\
\text { Papain }\end{array}$ & $\begin{array}{c}\text { After treatment with } \\
\text { Neutral Protease }\end{array}$ \\
\hline \multirow{2}{*}{$\begin{array}{c}\text { Mung bean seed } \\
\text { protein }\end{array}$} & Micrococcus luteus & 40.0 & 40.0 \\
\cline { 2 - 4 } & Bacillus subtilis & 40.0 & 30.0 \\
\cline { 2 - 4 } & Bacillus spreader & 30.0 & 25.0 \\
\hline \multirow{2}{*}{$\begin{array}{c}\text { Gram white seed } \\
\text { protein }\end{array}$} & Micrococcus luteus & 30.0 & 11.0 \\
\cline { 2 - 4 } & Bacillus subtilis & 20.0 & 16.0 \\
\cline { 2 - 4 } & Bacillus spreader & 11.0 & 13.0 \\
\hline \multirow{2}{*}{$\begin{array}{c}\text { Gram brown } \\
\text { seed protein }\end{array}$} & Micrococcus luteus & 35.0 & 15.0 \\
\cline { 2 - 4 } & Bacillus subtilis & 25.0 & 11.0 \\
\cline { 2 - 4 } & Bacillus spreader & 20.0 & 15.0 \\
\hline
\end{tabular}

Table.2 Antimicrobial activity of the protein samples extracted

\begin{tabular}{|c|c|}
\hline Parameters determined & Inference \\
\hline Colour & Dirty white as appeared after ammonium sulphate precipitation \\
\hline Solubility & $100 \%$ soluble \\
\hline $\mathrm{pH}$ & 6.23 \\
\hline
\end{tabular}

Table.3 Effect of proteolytic enzymes on the antimicrobial activity of the extracted protein

\begin{tabular}{|c|c|c|}
\hline Types of seeds protein & Strains & Diameter of zone of inhibition (mm) \\
\hline \multirow[t]{3}{*}{ Mung bean seed protein } & Micrococcus luteus & 40.0 \\
\hline & Bacillus subtilis & 59.0 \\
\hline & Bacillus (spreader) & 49.0 \\
\hline \multirow[t]{3}{*}{ Gram White seed protein } & Micrococcus luteus & 40.0 \\
\hline & Bacillus subtilis & 25.0 \\
\hline & Bacillus (spreader) & 25.0 \\
\hline \multirow[t]{3}{*}{ Gram brown seed protein } & Micrococcus luteus & 40.0 \\
\hline & Bacillus subtilis & 28.0 \\
\hline & Bacillus (spreader) & 25.0 \\
\hline \multirow[t]{3}{*}{ Erythromycin (1 mg/ml) } & Micrococcus luteus & 45.0 \\
\hline & Bacillus subtilis & 32.0 \\
\hline & Bacillus (spreader) & 27.0 \\
\hline
\end{tabular}

Table.4 Effect of temperature on the antimicrobial activity of the extracted protein

\begin{tabular}{|c|c|c|c|c|c|}
\hline \multirow{2}{*}{$\begin{array}{l}\text { Types of seeds } \\
\text { protein }\end{array}$} & \multirow{2}{*}{ Strains } & \multicolumn{4}{|c|}{ Temperature } \\
\hline & & $4^{\circ} \mathrm{C}$ & $25^{\circ} \mathrm{C}$ & $30^{\circ} \mathrm{C}$ & $50^{\circ} \mathrm{C}$ \\
\hline \multirow{3}{*}{$\begin{array}{l}\text { Mung bean seed } \\
\text { protein }\end{array}$} & Micrococcus luteus & 12.0 & 22.5 & 24.0 & 9.0 \\
\hline & Bacillus subtilis & 13.0 & 26.0 & 27.5 & 5.0 \\
\hline & Bacillus spreader & 10.0 & 28.0 & 28.0 & 7.0 \\
\hline \multirow{3}{*}{$\begin{array}{c}\text { Gram White seed } \\
\text { protein }\end{array}$} & Micrococcus luteus & 12.0 & 25.0 & 26.0 & 10.0 \\
\hline & Bacillus subtilis & 13.0 & 26.0 & 28.0 & 8.0 \\
\hline & Bacillus spreader & 10.0 & 25.0 & 27.0 & 6.0 \\
\hline \multirow{3}{*}{$\begin{array}{c}\text { Gram Brown seed } \\
\text { protein }\end{array}$} & Micrococcus luteus & 15.0 & 18.0 & 19.0 & 10.0 \\
\hline & Bacillus subtilis & 11.0 & 18.0 & 17.0 & 8.0 \\
\hline & Bacillus spreader & 16.0 & 19.0 & 17.0 & 10.0 \\
\hline
\end{tabular}


Table.5 Effect of $\mathrm{pH}$ on the antimicrobial activity of the extracted protein

\begin{tabular}{|c|c|c|c|c|c|}
\hline Types of seeds protein & Strains & \multicolumn{4}{|c|}{ pH } \\
\cline { 2 - 6 } & & $\mathbf{2}$ & $\mathbf{4}$ & $\mathbf{5}$ & $\mathbf{7}$ \\
\hline \multirow{3}{*}{ Mung bean seed protein } & Micrococcus luteus & 20.0 & 22.0 & 24.0 & 23.0 \\
\cline { 2 - 6 } & Bacillus subtilis & 20.0 & 25.0 & 25.0 & 22.0 \\
\cline { 2 - 6 } & Bacillus spreader & 11.0 & 24.0 & 25.0 & 13.0 \\
\hline \multirow{3}{*}{ Gram White seed protein } & Micrococcus luteus & NA & 20.0 & 25.0 & 30.0 \\
\cline { 2 - 6 } & Bacillus subtilis & NA & 20.0 & 25.0 & 30.0 \\
\cline { 2 - 6 } & Bacillus spreader & NA & 18.0 & 20.0 & 22.0 \\
\cline { 2 - 6 } Gram Brown seed protein & Micrococcus luteus & 12.0 & 15.0 & 17.0 & 18.0 \\
\cline { 2 - 6 } & Bacillus subtilis & 12.0 & 14.0 & 16.0 & 17.0 \\
\cline { 2 - 6 } & Bacillus spreader & 20.0 & 21.0 & 23.0 & 25.0 \\
\hline
\end{tabular}

Table.6 TPC ( $\mu \mathrm{g} / \mathrm{g}$ gallic acid equivalents) of extracted protein samples

\begin{tabular}{|c|c|}
\hline Protein samples/Standard & TPC $(\boldsymbol{\mu g} / \mathbf{g}$ gallic acid equivalent) \\
\hline Standard (Gallic acid) & 55.56 \\
\hline Mung bean seed protein & 25.0 \\
\hline Gram White seed protein & 28.0 \\
\hline Gram Brown seed protein & 22.2 \\
\hline
\end{tabular}

Table.7 Percent inhibition of superoxide anion radical scavenging

Activity of extracted protein samples

\begin{tabular}{|c|c|}
\hline Protein samples/Standard & Percent inhibition of superoxide anion radical scavenging activity \\
\hline Ascorbic acid & 65.67 \\
\hline Mung bean seed protein & 56.45 \\
\hline Gram White seed protein & 58.23 \\
\hline Gram Brown seed protein & 62.34 \\
\hline
\end{tabular}

Table.8 Total antioxidant activity of extracted protein samples

\begin{tabular}{|c|c|}
\hline Protein samples/Standard & Total antioxidant activity (A695 nm) \\
\hline Ascorbic acid & 0.06 \\
\hline Mung bean seed protein & 0.04 \\
\hline Gram White seed protein & 0.07 \\
\hline Gram Brown seed protein & 0.05 \\
\hline
\end{tabular}

Image.1 Mung bean seeds

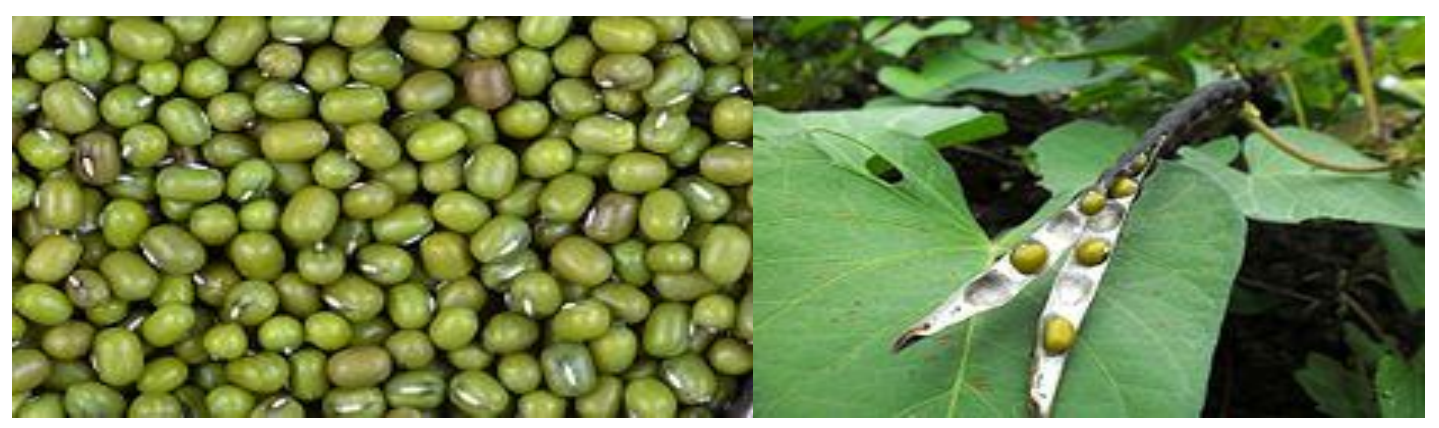


Image.2 Bengal gram (white and brown)

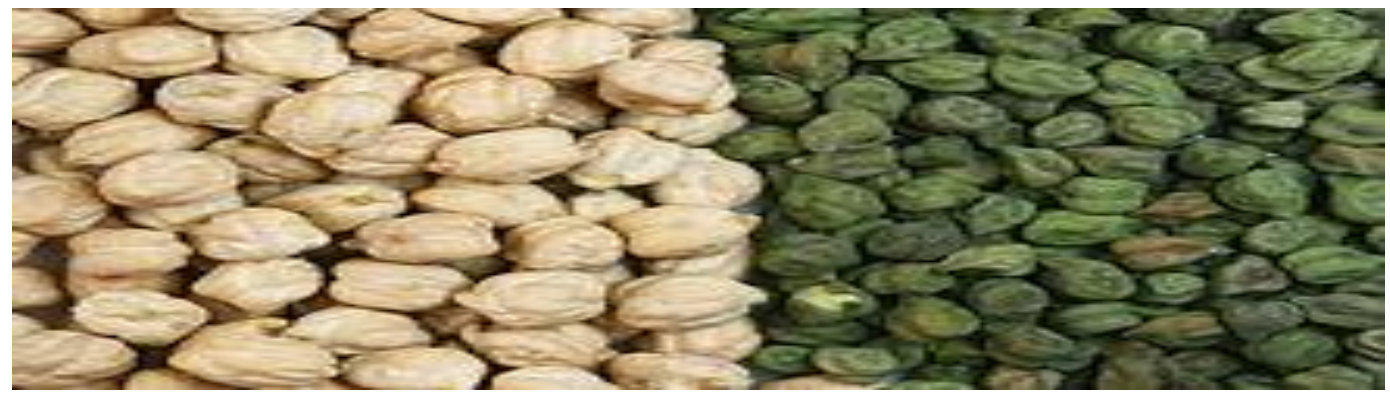

Fig.1 (a) Graphical representation of the protein samples isolated and purified

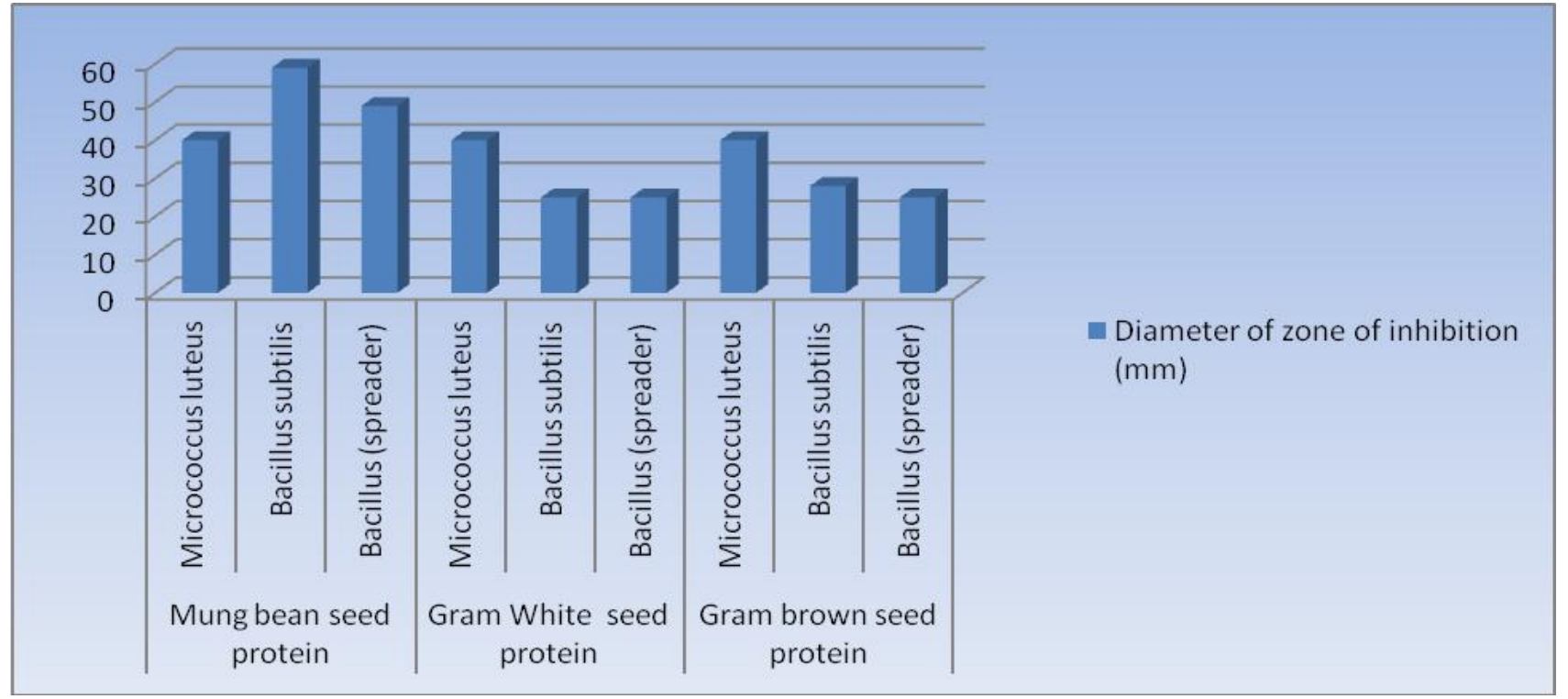

Fig.1 (b) Antimicrobial activity of protein samples isolated and purified

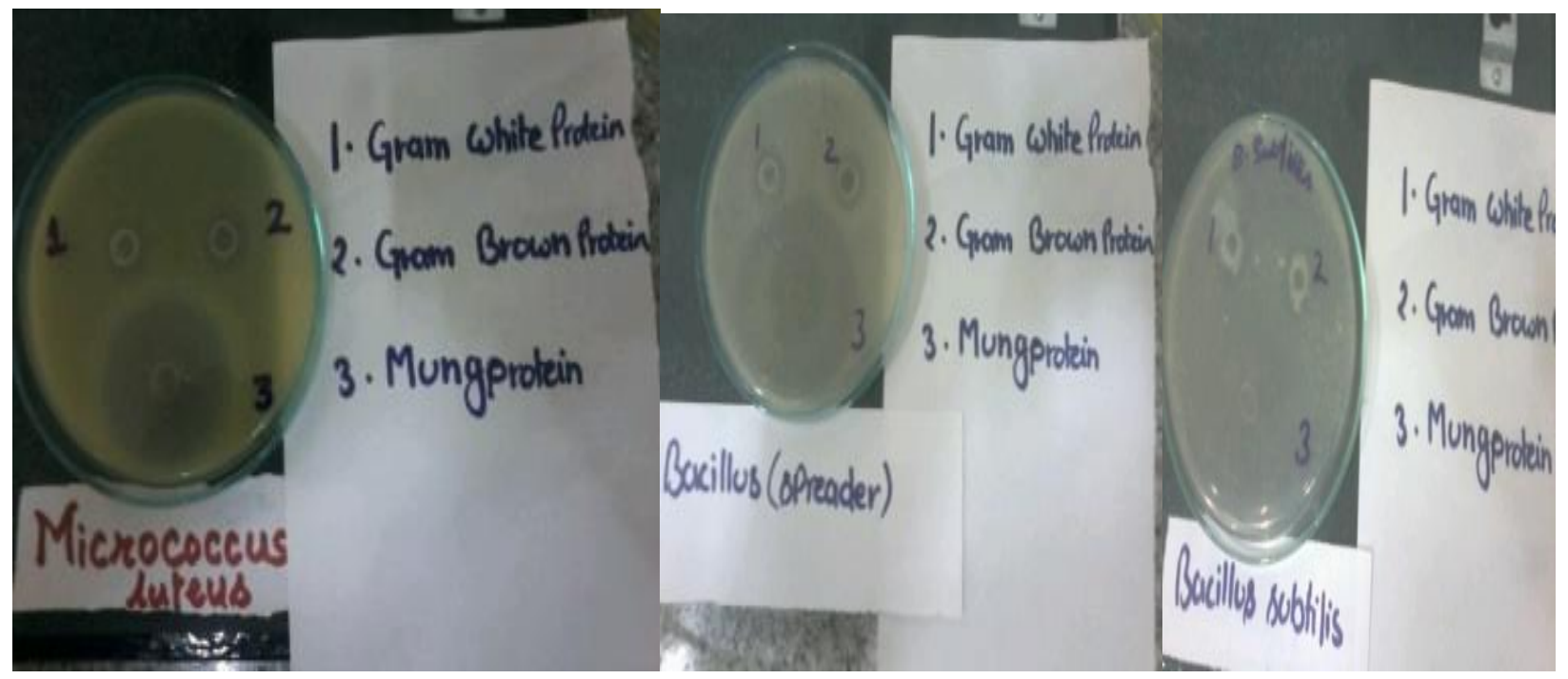


Fig.2 Graphical representation of the effect of proteolytic enzymes on the antimicrobial activity of the extracted protein

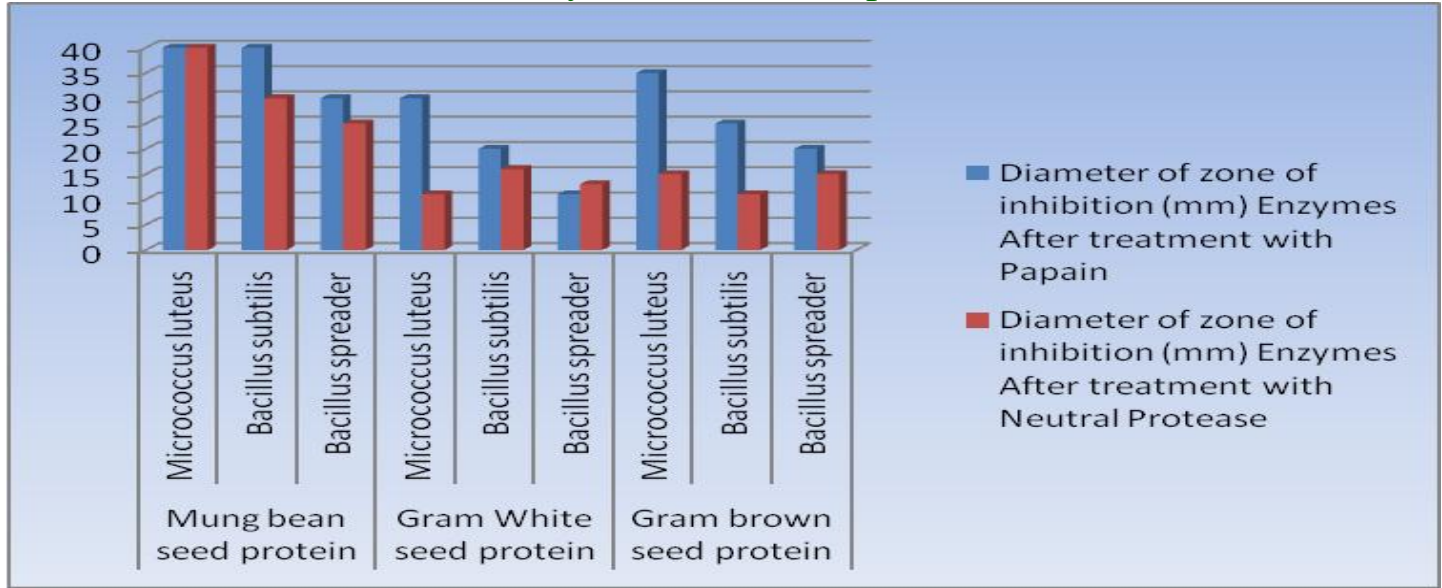

Fig.3 Graphical representation of effect of temperature on the antimicrobial activity of the extracted protein

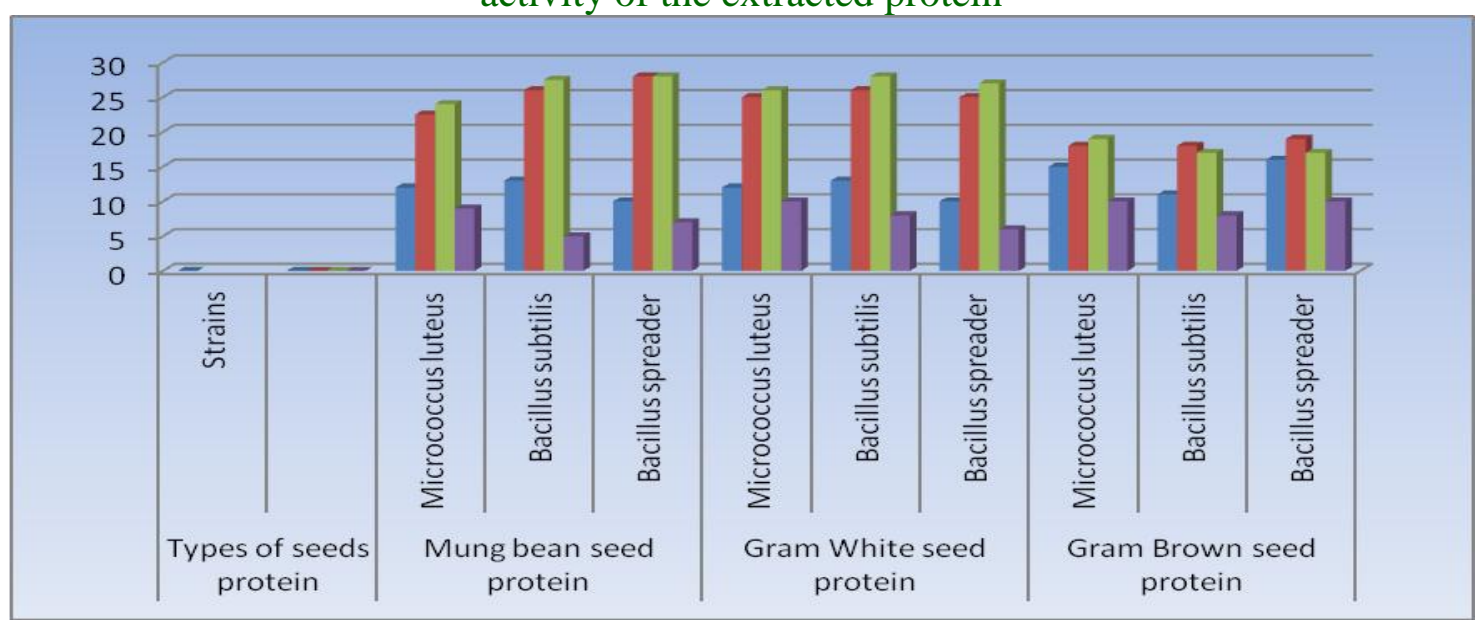

Fig.4 Graphical representation of the effect of $\mathrm{pH}$ on the antimicrobial activity of the extracted protein

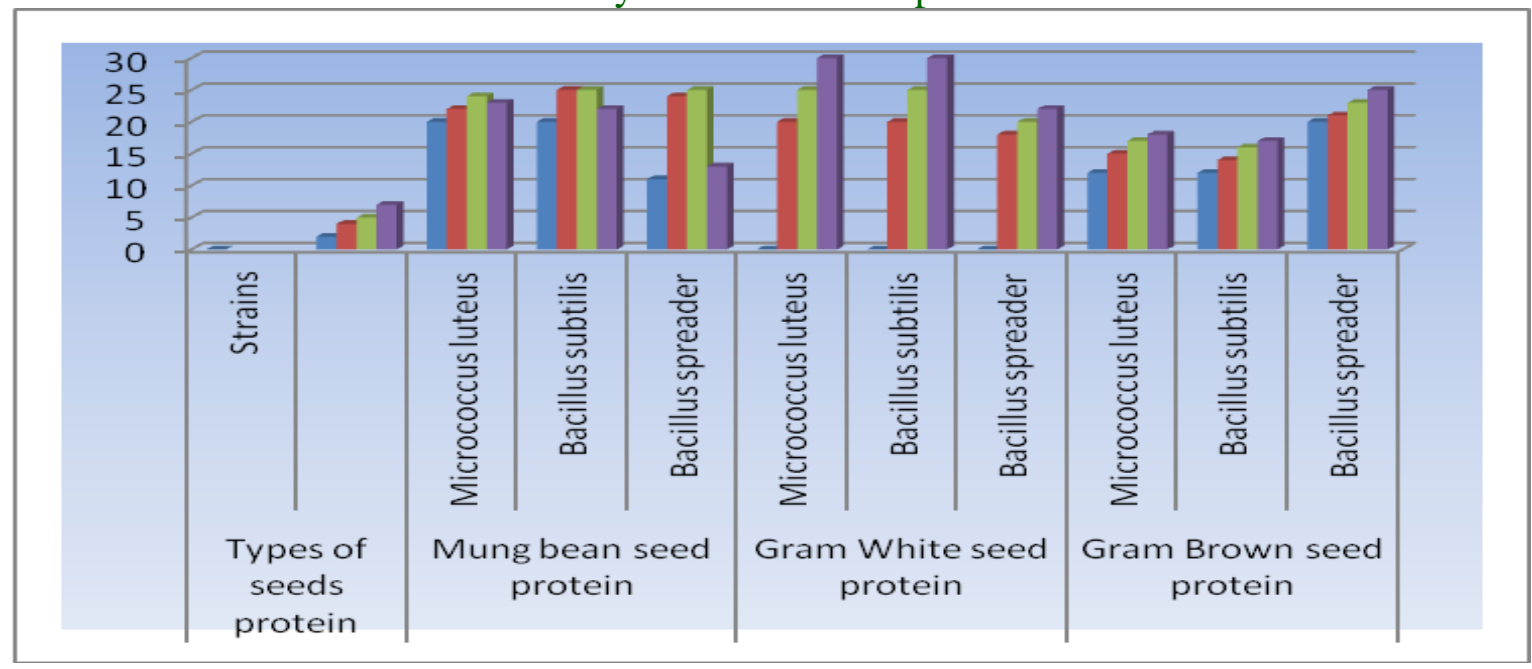


Fig.5 Graphical representation of TPC $(\mu \mathrm{g} / \mathrm{g}$ gallic acid equivalents) of extracted protein samples

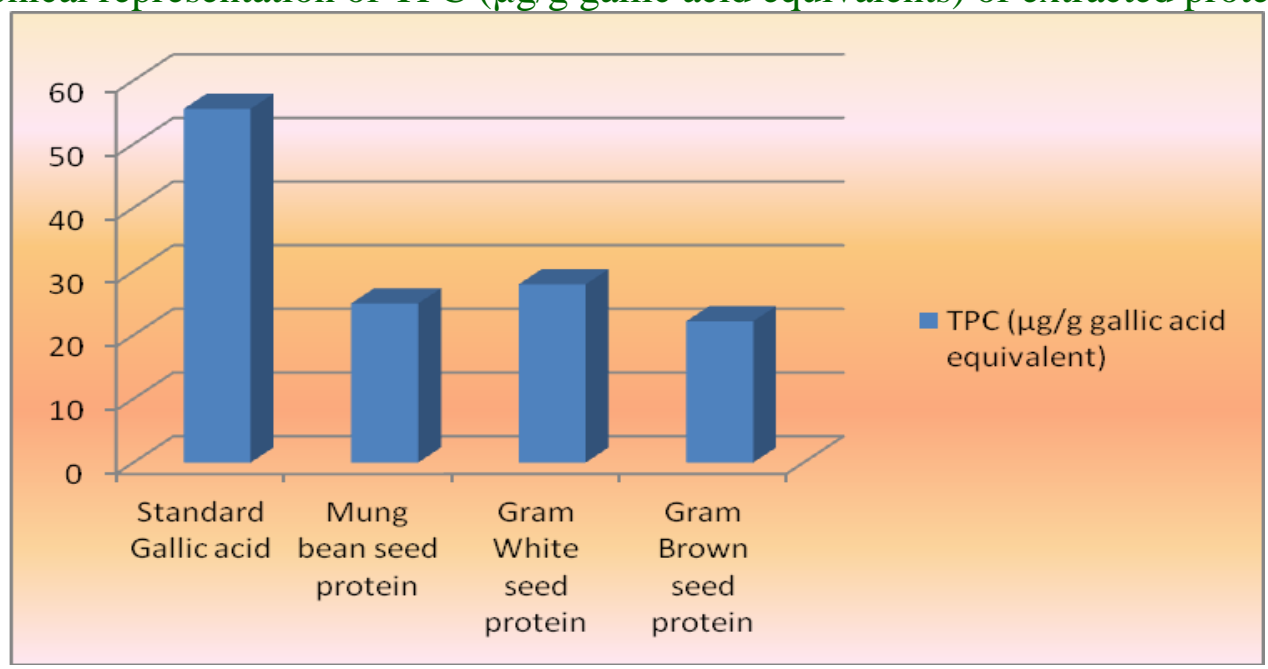

Fig.6 Graphical representation of percent inhibition of superoxide anion radical scavenging activity of extracted protein samples

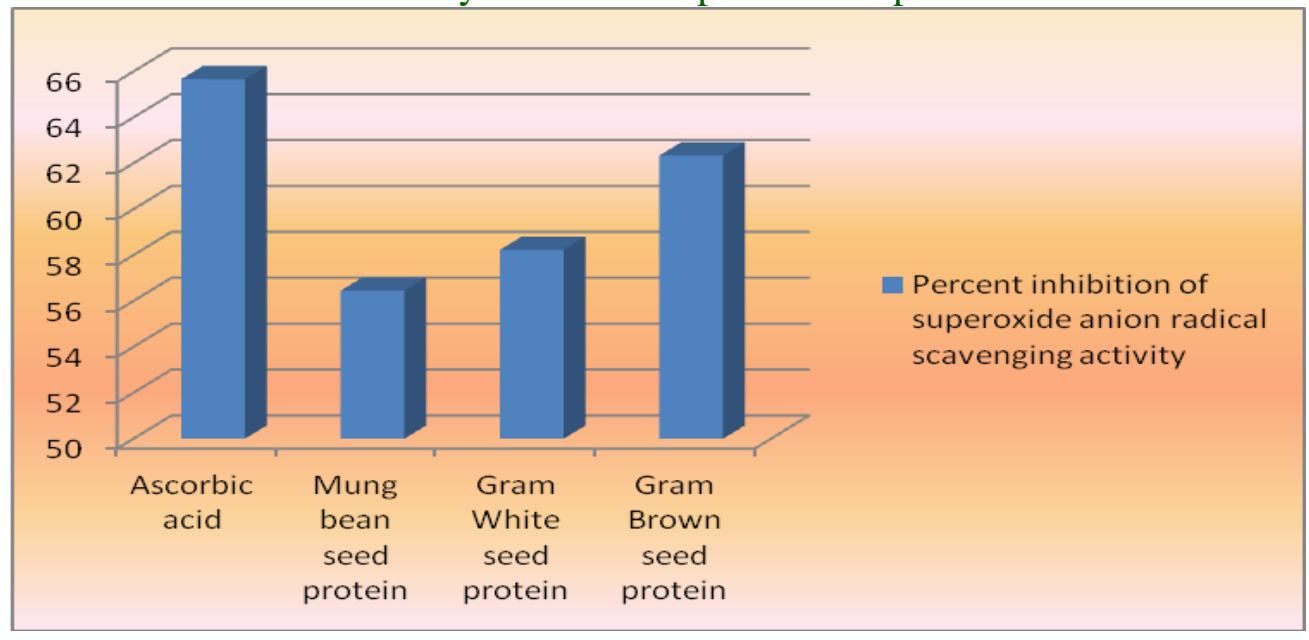

Fig.7 Graphical representation of total antioxidant activity of extracted protein samples

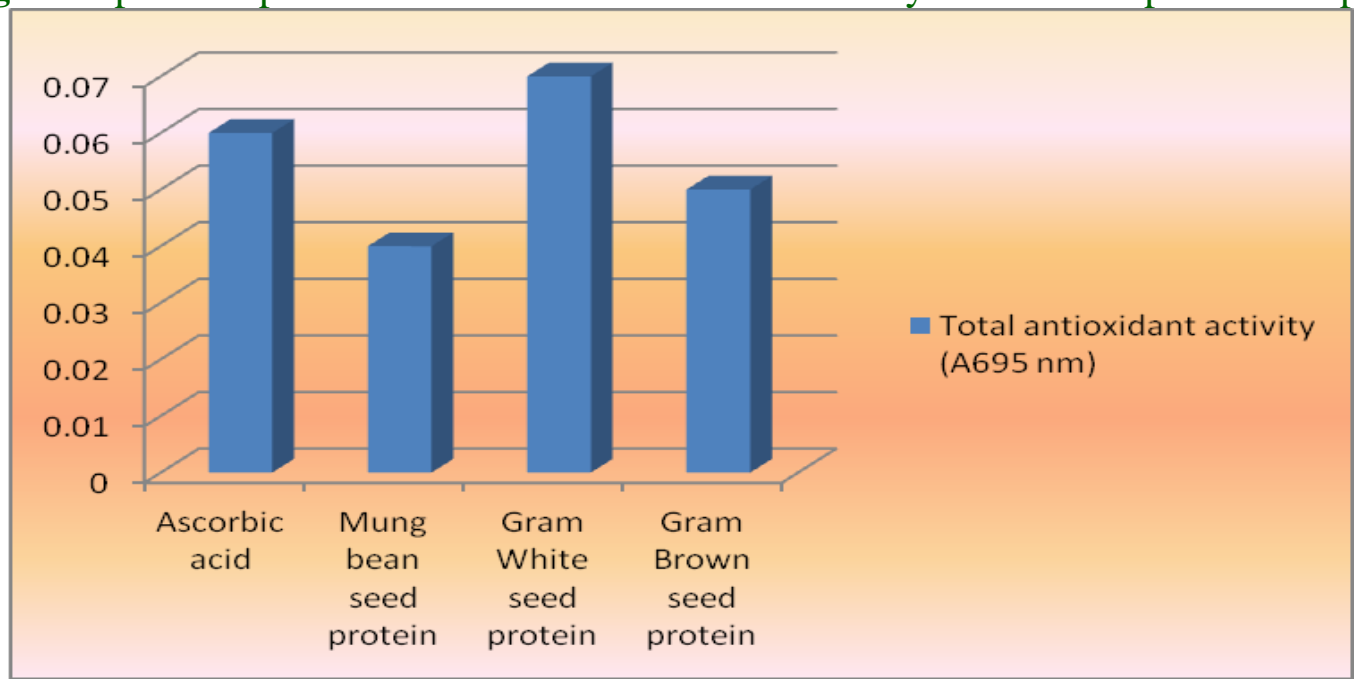


In conclusion, the present study suggests the importance of protein in leguminous pulses seeds. The results describe the potent antimicrobial and antioxidant properties in these proteins. The results thus suggested that, these proteins after purification can act as strong antimicrobial and antioxidant agent. The identification of sequence of amino acids in these proteins and their comparative representation can tell us the types of amino acids responsible for such pharmacological action. However structure elucidation of such proteins will also be a strong parameter to establish the structure-activity relationship of these proteins.

\section{References}

Anonymous. 2008. World Health Organization. Traditional Medicine. Fact sheet. www.who.int/mediacentre/factsheets/f s134/en/

Duan X, Wu G and Jiang Y. Evaluation of the antioxidant properties of litchi fruit phenolics in relation to pericarp browning prevention. Molecules, 2007; 12(4):759-771.

Feng, J., F. Yuani, Y. Gao, C. Liang, J. Xu, C. Zhang and L. He. 2003. A novel antimicrobial protein isolated from potato (Solanum tuberosum) shares homology with an acid phosphatase. $J$. Biochem., 376(2): 481-487.

Gao AG, Hakimi SM, Mittanck CA, Wu Y, Woerner BM, Stark DM, Shah DM, Liang J, Rommens CM (2000) Fungal pathogen protection in potato by expression of a plant defensin peptide. Nat Biotechnol., 18: 1307-1310

Hu, S.H., J.C. Wang, H.F. Kung, J.T. Wang, W.L. Lee and Y.H. Yang. 2004. Antimicrobial effect of extracts of cruciferous vegetables. Kaohsiung $J$. Med Sci., 20(12): 591-599.
Jabi S., Mathur A. 2017. Study of the antimicrobial effect of the protein fraction isolated from germinated Vigna radiata (Mung bean) seeds. Int. J. Sci. Res. Pub., 7(3):158-163.

Jaladi AMP, Dokka MK, Shiva Prasad D. (2015). Purification of acid phosphatase from Ginger (Zingiber officinale) rhizomes. International Journal of Advanced Research, 3(1): 10-20.

Laemmli UK. (1970). Cleavage of structural proteins during the assembly of the head of bacteriophage T4. Nature, 227(5259): 680-685.

Lowry $\mathrm{OH}$, Rosebrough NJ, Farr AL and Randall RJ. (1951). Protein measurement with Folin phenol reagent. J. Biol. Chem., 193: 265- 275.

Mariangela, S., S. Diz, A.O. Carvalho, R. Rodrigues, A.G.C. Neves-Ferreira, M.D. Cunha, E.W. Alves, A.L. Okorokova-Façanha, M.A. Oliveira, J.Perales, O.L.T. Machado and V.M. Gomes. 2006. Antimicrobial peptides from chilli pepper seeds causes yeast plasma membrane permeabilization and inhibits the acidification of the medium by yeast cells. Biochem. et Biophys Acta. 1760(9):1323-1332

Marx, V. 2005. Watching peptide drugs grow up. J. Chem and Eng. News, 83(11): 17-24.

Ngai, P.H. and T.B. Ng. 2004. A napin-like polypeptide from dwarf Chinese white cabbage seeds with translation inhibitory, trypsin-inhibitory, and antibacterial activities. J. Peptides., 25(2): 171-6.

Ngai, P.H., Z. Zhao and T.B. Ng. 2005. Agrocybin, an antifungal peptide from the edible mushroom Agrocybe cylindracea. J. Peptides., 26(2): 191-6.

Oard, S., M.C. Rush and J.H. Oard. 2004. Characterization of antimicrobial peptides against a US strain of the rice 
pathogen Rhizoctonia solani. J. Appl. Microbiol., 97(1):169-80.

Pasha C, Golla K, Vutukuru SS, Rani JU, Meghanath P. (2016). Screening of small peptides from germinating seeds having antimicrobial activity. IOSR Journal of Pharmacy and Biological Sciences, 11(1): 52-60.

Perez C, Anesini C. 1993. In vitro antimicrobial activity of Argentine folk medicinal plants against Salmonella typhii. Journal of Ethno pharmacology, 44: 41-46.
Singleton VL and Rossi JA. 1965. Colorimetry of total phenolics with phosphomolybdic and phosphotungstic acid reagents. American Journal of Ecology and Viticulture, 16: 144-158.

Xia, L. and T.B. Ng. 2005. Isolation of alliumin, a novel protein with antimicrobial and antiproliferative activities from multiple-cloved garlic bulbs. J. Peptide., 26(2): 177-183.

Wright, G.D. 2000. Resisting resistance: new chemical strategies for battling superbugs. J. Chem and Bio, 7(6): $127-132$.

\section{How to cite this article:}

Shahana Jabi and Abhishek Mathur. 2017. Study of the Optimal Physical Parameters and Action of the Proteolytic Enzyme on the Antimicrobial and Antioxidant Potential of the Protein Isolated from Different Pulses. Int.J.Curr.Microbiol.App.Sci. 6(8): 1523-1533. doi: https://doi.org/10.20546/ijcmas.2017.608.183 